\title{
The Quaternary sequence of Mecklenburg-Western Pomerania: areas of specific interest and ongoing investigations
}

\author{
Andreas Börner ${ }^{1}$, Anna Gehrmann ${ }^{2}$, Heiko Hüneke ${ }^{2}$, Michael Kenzler $^{2}$, and Sebastian Lorenz ${ }^{2}$ \\ ${ }^{1}$ Geological Survey of Mecklenburg-Western Pomerania, LUNG M-V, Goldberger Strasse 12, 18273 Güstrow, Germany \\ ${ }^{2}$ Greifswald University, Institute for Geography and Geology, Friedr.-Ludwig-Jahn Str. 17a, 17489 Greifswald, Germany
}

Correspondence: $\quad$ Andreas Börner (andreas.boerner@lung.mv-regierung.de)

Relevant dates: $\quad$ Published: 15 August 2019

How to cite: $\quad$ Börner, A., Gehrmann, A., Hüneke, H., Kenzler, M., and Lorenz, S.: The Quaternary sequence of Mecklenburg-Western Pomerania: areas of specific interest and ongoing investigations, DEUQUA Spec. Pub., 2, 1-10, https://doi.org/10.5194/deuquasp-2-1-2019, 2019.

Abstract:

This paper aims to combine the knowledge of more than 100 years of Quaternary research in Mecklenburg-Western Pomerania (Geinitz, 1922; Deecke, 1907; Schulz, 1967, 1971; von Bülow, 2000; Rühberg et al., 1995; Müller et al., 1995; Katzung, 2004; Kenzler et al., 2015, 2018) including a summary of the areas of specific interest, a general overview of the most recent scientific results and of the ongoing investigations presented during the Field Symposium of the INQUA PeriBaltic Working Group 2019.

\section{Dedication}

This article is dedicated to Werner Schulz (1932-2018) and all active Quaternary field geologists for their important input during the last decades.

\section{Quaternary sedimentary record and} environmental change in northeastern Germany

\subsection{Early and Middle Pleistocene (2.6-0.3 Ma)}

The oldest Pleistocene deposits are located in the SW of Mecklenburg-Western Pomerania (MWP) and consist of fluvial gravel (von Bülow, 2000) with a mixed provenance of northern and southern source area (lydites and porphyrites). These fluvial deposits ("Loosen-Formation") were assigned to the Early Pleistocene (Rühberg et al., 1995; von Bülow and Börner, 2019; see Fig. 1). In the buried, over-deepened erosional channels near Hagenow (SW Mecklenburg), the base of the Pleistocene is found at a maximum depth of $550 \mathrm{~m}$. Here, the greatest thickness of Pleistocene deposits in
MWP (427 m) has been observed. Glaciofluvial sands overlie the oldest cold climate sediments at the base of this channel structure. Proglacial deposits of an Elsterian ice advance (400-320 ka; Litt et al., 2007) indicate the change to the first complete glacial-interglacial cycle. During the Elsterian deglaciation, glaciolacustrine sediments were deposited, such as the more than $100 \mathrm{~m}$ thick fine-grained sequence of the "Lauenburg Clay" in the lower Elbe area (SW Mecklenburg, Müller, 2004a). Palynological data from the upper part of the Lauenburg Clay sequence indicate the change from sub-arctic climate conditions to the warmer climate of the Holsteinian Interglacial (320-300 ka; German Stratigraphic Commission, 2016).

\subsection{The Holsteinian Complex (320-300 ka)}

In the area of MWP, the Holsteinian marine transgression occurred during pollen zone 4 and finished after Holsteinian pollen zone 5 (according to the pollen zones of Erd, 1973). The related marine-brackish deposits are not only restricted to the system of over-deepened Elsterian chan- 


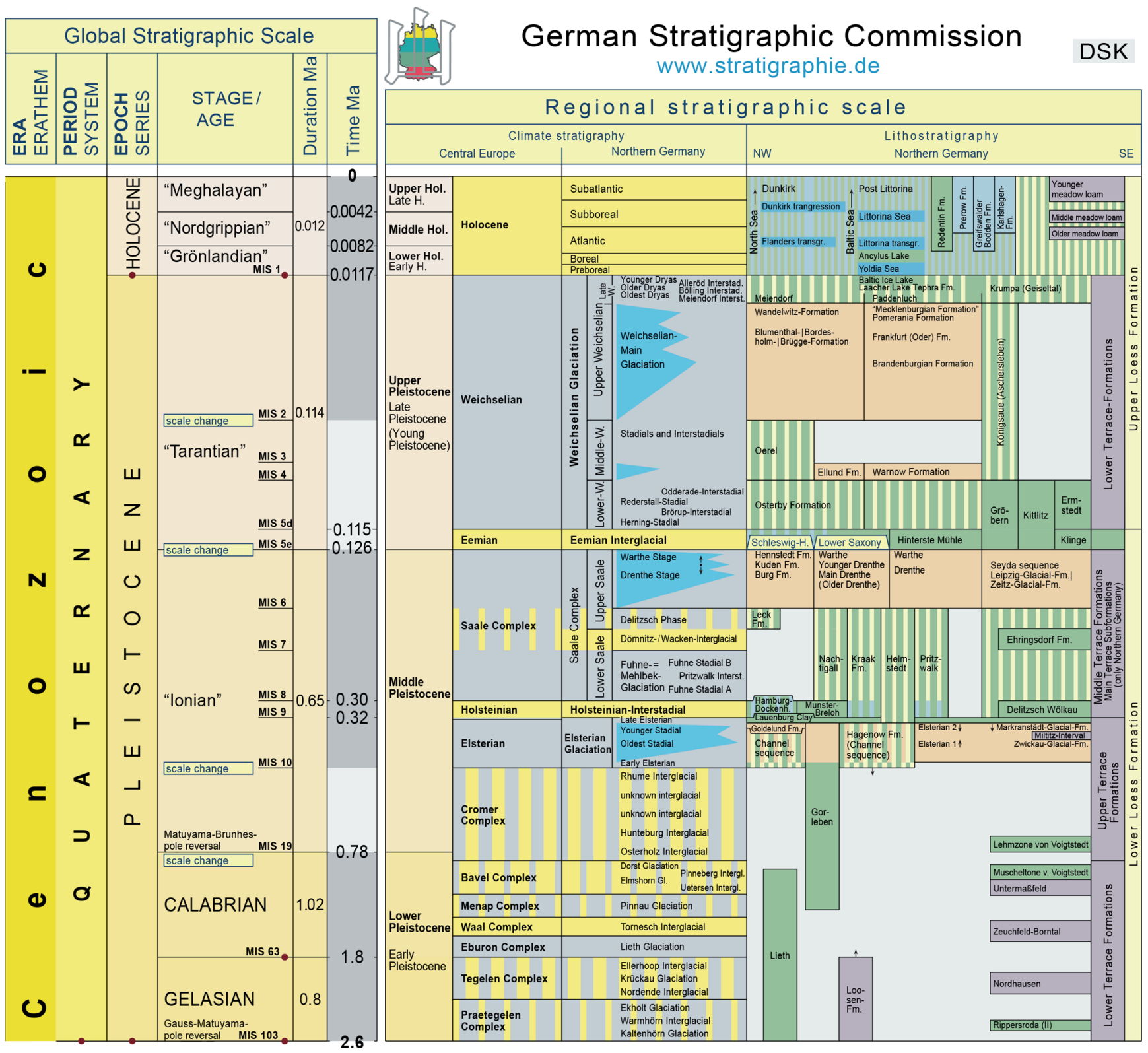

Figure 1. Quaternary stratigraphy of northern Germany (modified after German Stratigraphic Commission, 2016; cf. Bittmann et al., 2018).

nels and basins, but also locally distributed across central Mecklenburg and the eastern adjacent area between Anklam and Neubrandenburg. Throughout the "Holsteinian Complex", fluvial deposits of southerly provenance are intercalated (Müller et al., 1995; von Bülow, 2000).

\subsection{The Saalian Complex (300-126 ka)}

Above the late Holsteinian deposits, silt layers occur at several localities with a pollen spectrum indicating cold, arctic climate conditions. These silts are classified as the Fuhne cold stage (Fig. 1). During the course of the first Saalian ice advance (MIS 6), coarse proglacial sands were deposited, increasing in thickness towards the south. A similar tendency has also been noted with regard to the respective Saalian till sheets (Müller et al., 1995). The "Drenthe" ice advance deposited a highly variable, frequently very thick qsDtill sheet, often containing lenses and rafts of redeposited allochthonous pre-Quaternary materials of Jurassic, Cretaceous and Tertiary ages. For large areas of MWP, this Saalian ice advance is responsible for the palaeo-morphology of the pre-Pleistocene substrate surface (Müller, 2004c). In the easterly parts of MWP, the clay-rich qsD-till constitutes a characteristic marker unit, with its green to blue-green matrix (incorporation of Tertiary clay) and high flint content (Cretaceous). Further inland, a compact Saalian till sheet is present, 
which splits further to the south into two individual till layers (qsD, qsWA), which may be separated locally by sand and gravel lenses possibly of englacial origin. Based on numerous drillings that have been sampled during the last 50 years, the conventional subdivision of the Saalian into a "Drenthe" and "Warthe" substage has proved to be valid (Fig. 1; Müller et al., 1995). In the northeasternmost parts of MWP (e.g. Rügen), this qsWA-till forms the main unit of the Saalian glaciation. For example, on the island of Rügen and in the coastal areas of Western Pomerania, only a discontinuous layer of Saalian till has been found (on Rügen mainly of the "Warthe substage").

\subsection{The Eemian Interglacial $(126-115 \mathrm{ka})$}

At several locations in MWP, Eemian sequences are preserved. For example, the transition from the Saalian deglaciation into the early Eemian (including the initial Eemian marine transgression) is documented in a sequence at the cliff of Klein Klütz Höved west of Wismar (Strahl et al., 1994; Menzel-Harloff and Meng, 2015; Kenzler et al., 2018). Furthermore, a lacustrine sequence comprising the complete transition from the Eemian into the Early Weichselian is well-documented at the outcrop "Hinterste Mühle" in Neubrandenburg (Rühberg, 1998 ; Rühberg et al., 1998; Börner et al., 2018), and the Eemian profiles of Banzin and Beckentin in the southwest of Mecklenburg have recently been investigated, yielding new palaeoecological and U-Th data (Börner et al., 2015; Rother et al., 2019). Hence, the number of sites with proven lacustrine Eemian deposits has increased markedly during recent years.

Marine deposits of Eemian age are largely restricted to the present coastal areas (Menzel-Harloff and Meng, 2015; Börner et al., 2018; Kenzler et al., 2018). Therefore, the palaeogeography of the Eemian Sea differs significantly from that of the Holsteinian Sea, and it closely resembles the recent land-sea distribution (Müller, 2004a). The "Eemian Warnow bay" (Fig. 1), where marine mollusc-bearing sands of Eemian age were deposited (Gehl, 1961; Müller, 2004b; Börner et al., 2018), is an exception. Another relic of the Eemian Interglacial is the greenish-coloured reduction zone in the upper part of the "m1" till (qsWA) of the Stoltera cliff section NW of Rostock. This zone is interpreted as a result of Eemian weathering and pedogenesis (Ludwig, 1964).

\subsection{The Early to Middle Weichselian (115-27 ka)}

The Lower and the beginning of the Middle Weichselian period are characterised by a repeated alternation of stadials and interstadials (e.g. Hermsdorf and Strahl, 2008). The existence of an Early to Middle Weichselian ice advance (Warnow advance, Müller, 2004a, b; Obst et al., 2017) reaching MWP has so far not been incontestably confirmed (Kenzler et al., 2018). A possible correlation of this Warnow advance with the Danish Ristinge advance (56-46 ka) has been proposed by Houmark-Nielsen (2010). However, because no absolute age data are available for the Warnow advance, the exact stratigraphic position is still unknown. One reason for this lack of data is the absence of deposits of Early to Middle Weichselian age in MWP. Hence, this time period is poorly documented across this area.

Sedimentological and geochronological results indicate that no ice advance reached the island of Rügen during MIS 3 (57-29 ka; Kenzler et al., 2015, 2017). Lacustrine and fluvial depositional environments dominated the steppe-like landscape at that time. A cooling phase during the transition from MIS 3 to MIS 2, which was possibly associated with the Klintholm advance (32 $\pm 2 \mathrm{ka}$; Houmark-Nielsen, 2010) known from Denmark, preceded the Last Glacial Maximum (LGM) with its massive Scandinavian Ice Sheet (SIS) advances (Kenzler et al., 2017). New luminescence ages for sandur deposits genetically related to the Brandenburgian ice marginal position (Lüthgens et al., 2010a, b, 2011) raised the possibility of a two-folded LGM in NE Germany (Lüthgens et al., 2011; Hardt et al., 2016), casting doubt on the traditional interpretations of the main Weichselian ice advances in this area.

\subsection{The Last Glacial Maximum (27-13 ka)}

We still only have limited knowledge about the depositional environments and processes, the oscillation of the SIS during the LGM and early Late Glacial, and especially the deglaciation sequence of NE Germany between 25 and $14 \mathrm{ka}$, which has only been locally dated. The first unequivocal evidence of a Weichselian ice advance reaching MWP has been dated at about 25-20 ka (Kenzler et al., 2015, 2017, 2018; PisarskaJamroży et al., 2018). This time roughly coincides with the palaeo-geographical reconstructions of the SIS extent in the southwestern Baltic Sea area by Hughes et al. (2016). This Late Weichselian glaciation created new landforms, such as end moraines, dead-ice holes or drumlins. Morphostratigraphical evidence, combined with provenance analyses of the till fine gravel $(4-10 \mathrm{~mm})$ content (TGL 25232, 1971), provides the basis for a subdivision into distinct classes (Nordic crystalline, Palaeozoic limestone and so on). The lowest member of the glacial sequence is the till sheet of the Brandenburgian Phase (W1B), together with its proglacial outwash deposits. Nearby the southern ice marginal zone till deposits of the W1B are often absent, which might be explained, at least partly, by solifluction and smoothing of the morphology due to the strong periglacial conditions during MIS 2 (Rühberg et al., 1995). The oscillating character of the $\mathrm{W} 1$ glaciation is documented in the deposits and end moraines of the Frankfurt(Oder) subphase (W1F), which is classified in NE Germany as a W1 readvance. In MWP both $\mathrm{W} 1$ subphases (W1B and $\mathrm{W} 1 \mathrm{~F}$ ) are preserved together in a single till layer with no clear lithostratigraphical differences (Rühberg and Krienke, 1977). After a subsequent short deglaciation phase, the SIS readvanced into NE Ger- 


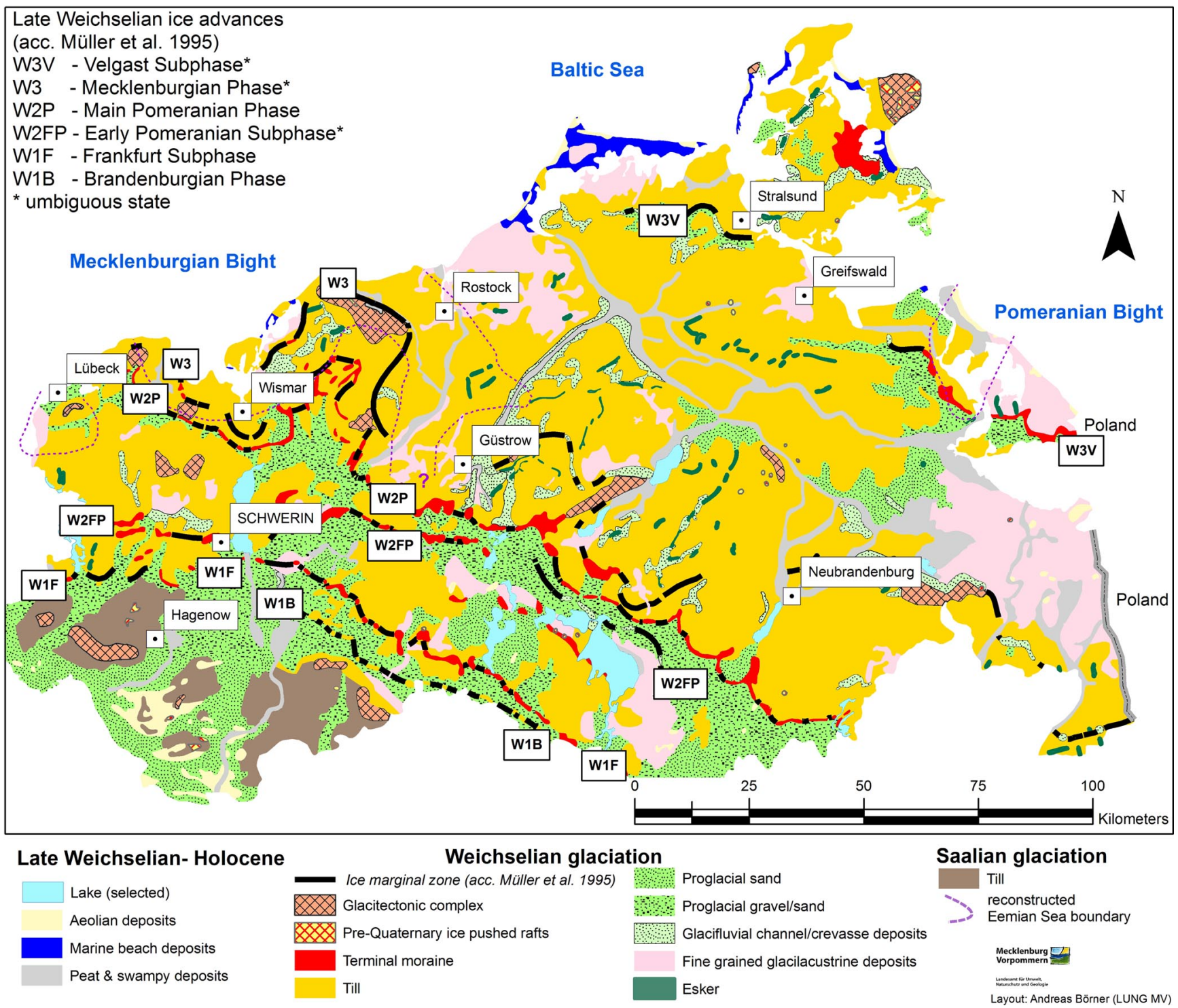

Figure 2. General geological map of Mecklenburg-Western Pomerania (based on Bremer, 2002; Müller, 2004b).

many (W2 - Pomeranian advance, Müller et al., 1995), which took place in two separated phases associated with distinct geomorphological features, such as different end moraines. The early Pomeranian advance (W2FP) pushed locally more southward as the "Pomeranian main advance" (W2P, Fig. 2), whereas the main Pomeranian advance formed pronounced end moraines, representing the main watershed between the catchment area draining into the Baltic Sea and the Elbe river catchment area flowing into the North Sea. The most important gravel and sand resources of MWP are related to the large proglacial outwash plain of the Pomeranian sandur areas. Based on recent work along the gas pipeline trenches crossing MWP (e.g. Börner et al., 2011; Börner and Müller, 2012), the place of the third Late Weichselian readvance of the "Mecklenburgian phase" (W3, Rühberg, 1987, Müller et al., 1995, Müller, 2004a), including the Velgast substage (W3V, Bremer, 2000), in the stratigraphic hierarchy remains controversial.

\subsection{The Late Weichselian deglaciation and the Holocene (13-0 ka)}

The landscape and the soil development in NE Germany show a clear relationship between the successive stages of the retreating SIS and the development of periglacial conditions (Liedtke, 1993). A first phase of intensified dead-ice melting, associated with intensive soil erosion, correlates with the Earliest Dryas and Bølling-Meiendorf (Terberger et al., 2004). Evidence for the presence of periglacial conditions and related soft-sediment deformations is found numerous in the soil profiles (Kopp, 1965, 1970). These "periglacial trans- 
formed" soils display zones of distinct signs of periglacial transformation, such as a high concentration of clay/silt, which resulted from congelifraction and other processes. The Geschiebedecksand "pebble cover sand" represents a stratigraphic marker of periglacial origin due to frost heave, deflation, aeolian sedimentation and finally destratification (Kopp, 1970). The transformation, duration and intensity of climate conditions during the Weichselian deglaciation and Holocene period, as well as the soil formation, have been investigated in detail on the Pomeranian outwash plains (Küster and Preusser, 2010) and were found to be mainly influenced by intensive aeolian deflation and deposition. Within the covers and layer, a brunic Arenosol has been identified in MWP (Lorenz et al., 2002, 2019; Kaiser et al., 2009), which is associated with the Allerød "Finow soil" in NE Brandenburg (Schlaak, 1993, 1998). The development of a dense vegetation cover during the Early Holocene resulted in stabilisation of the landscape surface and subsequent soil formation. Often the dead-ice melting was followed by the formation of small lakes. Near Dobbertin at the Mildenitz river basin, the late glacial melting of buried dead ice occurred $14.5 \mathrm{kyr}$ ago (Zawiska et al., 2014). The melting phase resulted in a reshaping of the lake basin morphology by new depressions, which were filled by glaciofluvial in- and outlets. Radiocarbon ages of buried birch trunks and basal peat indicate a first peat formation soon after the beginning of the Weichselian Late Glacial period ("Meiendorf-Interstadial", Fig. 1). The postglacial river-lake system in NE Germany was part of an immature drainage framework located along the Weichselian belt of northern central Europe. Frequent and abrupt changes in flow direction and the presence of numerous stagnant ice depressions occurred in the river valley (Lorenz and Schult, 2004; Kaiser et al., 2007; Błaszkiewicz, 2011). During the Allerød interstadial, the lake levels declined and fluvial activity decreased. As a consequence of the expansion of Betula-Pinus forests, soil erosion decreased and mainly organic sediments were deposited in the basins.

The oldest known human settlement in NE Germany, the elk-hunter camp at the Endingen archaeological site west of Stralsund, has been physically dated to the early Allerød (Kaiser et al., 1999). Remains of giant deer and horse indicate the existence of open parts in the landscape (Benecke, 2000). The pollen succession from a limnic section shows a palynostratigraphy ranging from the "Bølling" (Hippophae phase) to the middle Allerød. The tephrostratigraphy of lake sediments at the Endinger Bruch site provides the first age model for the Late Glacial palynological records of NE Germany (Lane et al., 2012). The cryptotephra contained six tephra layers of volcanic eruptions from Germany and Iceland spanning from the open vegetation phase I (Bølling) to the Early Holocene Betula-Pinus forest phase (Preboreal, $10.5 \mathrm{ka}$ ). Especially the Laacher See Tephra (12.9 ka cal BP, Eifel Volcanic Field in NW Germany) is present in very high concentrations within sediments of the Allerød phase (Lane et al., 2012).
The Younger Dryas (YD) is associated with a marked increase in fluvial and aeolian sedimentation, and lake-level high stands (Lorenz, 2007; Kaiser et al., 2007). In the open landscape during the YD, the soil erosion activity increased again and fluvial dynamics enlarged. There are clear indications of increasing aeolian activity mainly in the second part of the YD cooling phase. The YD in NE Germany was followed by Early Holocene lake-level low stands and a subsequent stabilisation phase with decreasing silicate input and increasing organic lacustrine deposition. The soil erosion was reduced and probably the final melting of the last remnants of buried dead ice blocks took place in the Preboreal (Terberger et al., 2004). The infilling continued until peat accumulation and terrestrialisation of lake basins became widespread during the Middle to Late Holocene. Beginning in the Late Holocene, the anthropogenic influence became important mainly through an increase in sediment supply due to deforestation and a rise in agricultural land use. In addition, mill stowage, river course corrections and anthropogenic lake-level modifications have increased stepwise since the 12 th century $\mathrm{CE}$.

\section{Areas of specific interest and ongoing research}

The peninsula of Jasmund on Rügen, located in the southwestern Baltic Sea area, is a landform that displays largescale glaciotectonic folding and thrusting (e.g. Steinich, 1972; Groth, 2003; Ludwig, 2011; Gehrmann and Harding, 2018). Late Cretaceous and Pleistocene deposits exposed along impressive sea cliffs form part of a major fold and thrust complex. It developed as a result of Late Weichselian glaciotectonism (ice-marginal glacial tectonics) associated with the highly dynamic Baltic Ice Stream. The latter drained the SIS in a south-westerly direction during the Late Weichselian and the peninsula of Jasmund was situated at its southern marginal zone (Lüthgens and Böse, 2011; Böse et al., 2012; Hughes et al., 2016; Hardt and Böse, 2018; Kenzler et al., 2018).

Detailed macro- and microstructural studies have developed a kinematic model to explain the bi-lobed structure and the internal architecture of the glaciotectonic complex (Gehrmann, 2018; Gehrmann et al., 2019). Sedimentlandform associations and flow-direction criteria derived from a variety of glacial deposits have been used to reconstruct successive glacial advances and retreats of this mobile ice sheet across the peninsula of Jasmund. The age of main ice advances and minor fluctuations have been reconstructed by luminescence dating in combination with lithostratigraphic, sedimentological and micromorphological investigations of the (glacio-)fluvial, lacustrine and aeolian deposits (e.g. Steinich, 1992; Panzig, 1995; Ludwig, 2006; Müller and Obst, 2006; Kenzler et al., 2017; Kenzler and Hüneke, 2019). The microfabrics within the tills laid down by the SIS have been studied by means of two- and three- 
dimensional analyses based on the microstructural mapping, which enables the identification and interpretation of the successive generations of fabrics in terms of a progressive, polyphase deformation history (Brumme, 2015; Brumme et al., 2019; Gehrmann et al., 2017, 2019; Mehlhorn et al., 2019). The orientation of these microfabrics can be directly related to changes in the regional ice-flow direction across the peninsula of Jasmund.

The strongly curved coastline of Western Pomerania is initially followed by a morphologically inconspicuous inland. The slightly undulating morainic areas with dominating ablation tills were most likely formed by rapid Late Weichselian glacier decay without oscillations from the ice margin of the Mecklenburgian Phase (Rühberg, 1987). Due to intense weathering, the predominantly loamy tills are characterised by cambic soils and partly hydromorphic Luvisols (Börner et al., 2012). From a regular network of subglacial channels, large ramified river valleys and mires emerged from the Late Weichselian onwards, mainly driven by a rising groundwater table since the Early Holocene, while lower river sections were influenced by the rising level of the Baltic Sea (Janke, 2002; Kaiser et al., 2012). A valley section of river Tollense near the village Weltzin about $25 \mathrm{~km}$ north of Neubrandenburg holds spectacular archaeological findings, attributed to violent conflicts in the Bronze Age about 3250 years ago (Jantzen et al., 2011; Lidke et al., 2018). Large quantities of human bones, arrowheads and other types of weapons, and metal findings have been preserved in the deposits of river Tollense. The assumed starting point of the battle is a pathway currently overgrown by peat, which crossed the river and surrounding mire (Jantzen et al., 2014). Results of archaeological excavations and interdisciplinary research on the found materials, as well as geoscientific results on the Bronze Age palaeoenvironment, are presented in Brinker et al. (2018), Flohr et al. (2015), Krüger et al. (2012), Lorenz et al. (2015), Price et al. (2017), and Lidke and Lorenz (2019).

The lake district of Mecklenburg ranges between the Weichselian ice marginal zones of the Brandenburgian and Pomeranian Phase with a broad variety of lakes and rivers (Rühberg, 1999; Kaiser et al., 2012; Janke, 2004). While some parts still belong to the Baltic Sea catchment, the larger lakes drain via tributary waters and eventually the river Elbe to the North Sea. Lake Müritz $\left(113 \mathrm{~km}^{2}, 62.1 \mathrm{~m}\right.$ a.s.l. $)$ is the largest lake of the Mecklenburg lake district and represents together with the city of Waren/Müritz the tourist centre of the area (Rühberg, 1999; Grundmann, 1999). South and northwest of the city large interconnected lakes, the so-called "Upper Lakes", can be found as relics of vast Pleniglacial and Late Glacial palaeolakes (Kaiser, 1998). In the southeastern continuation of the lake district, smaller lakes and chains of lakes characterise the landscape (Küster et al., 2012). During the last decade, geoscientific research has focused on Holocene palaeohydrology and morphogenesis of lakes and river valleys, and the pedological tracing of land use history (Kaiser et al., 2012, 2015; Küster, 2014; Lampe et al., 2009).
Typical sections of the lake landscapes are protected in the Müritz National Park, while the nature experience centre Müritzeum in Waren exhibits collections of indicator boulders, fossils, plants and animals (Küster, 2019).

The lacustrine basins of Krakower See and Tiefer See are genetically related to glaciofluvial incision very close to the ice margin of the Pomeranian Phase, followed by a delayed thawing of buried dead ice between the Meiendorf Phase and the Preboreal with remarkable lake-level fluctuations. Detailed palaeoenvironmental studies on lake sediments, and pedological and geomorphological studies on lake terraces, palaeosoils and adjacent river valleys have been used to reconstruct Weichselian Late Glacial and Holocene lake-level fluctuations and Holocene land-use history (e.g. Kaiser et al., 2007; Lorenz, 2008). While Krakower See exhibits two lake terraces with littoral landforms such as beach ridges and palaeosoils (Lorenz, 2007), Tiefer See basin is remarkably deeply incised with a narrow littoral zone, which allowed varve formation during long parts of the Holocene (Kienel et al., 2013). In addition to various sediment cores, Tiefer See was equipped with multi-purpose samplers and measuring devices to establish an interdisciplinary field laboratory for the ICLEA Helmholtz Institute (Schwab et al., 2017; Brauer et al., 2019). The applied combination of long-term highresolution varve analyses with in situ sampling of present detrital components on the lake bottom and dendroecological analyses has revealed complex coupled processes working at different timescales (Czymzik et al., 2015; Dräger et al., 2014; Theuerkauf et al., 2015; van der Maaten et al., 2015).

Data availability. All data relevant for this contribution are presented within the article itself or the publications cited (key publications are Küster et al., 2012; Börner et al., 2012; Kenzler et al., 2017).

Author contributions. $\mathrm{AB}$ wrote the first draft of the manuscript and developed the illustrations. MK re-wrote part of the text and translated the stratigraphic table. AG, HH, MK and SL wrote the chapter about the regional geology of specific areas of interest. All authors contributed to the discussion and interpretation of the presented research results.

Competing interests. The authors declares that there is no conflict of interest.

Acknowledgements. We acknowledge support for the article processing charge from the DFG (no. 393148499) and the Open Access Publication Fund of the University of Greifswald. The contribution benefited from the critical comments of an unknown reviewer. We thank Marie-Elaine van Egmond (Halle) professional English proofreading. 
Financial support. This research has been supported by the DFG (German Research Foundation, grant no. 393148499) and the Open Access Publication Fund of the University of Greifswald.

\section{References}

Benecke, N.: Die jungpleistozäne und holozäne Tierwelt Mecklenburg-Vorpommerns, Beiträge zur Ur- und Frühgeschichte Mitteleuropas, 23, 143 pp., 2000.

Bittmann, F., Börner, A., Doppler, G., Ellwanger, D., Hoselmann, C., Katzschmann, L., Sprafke, T., Strahl, J., Wansa, S., WielandtSchuster, U., and Subkommission Quartär der Deutschen Stratigraphischen Kommission: Das Quartär in der Stratigraphischen Tabelle von Deutschland 2016, Z. Dtsch. Ges. Geowiss., 169, 295-306, 2018.

Błaszkiewicz, M.: Timing of the final disappearance of permafrost in the central European Lowland, as reconstructed from the evolution of lakes in N Poland, Geol. Q., 55, 361-374, 2011.

Börner, A. and Müller, U.: Lithologie und Lithostratigraphie von oberfl ächennahen Tillhorizonten der OPAL-Trasse in Mecklenburg-Vorpommern [Lithology and lithostratigraphy of near surface till layers from OPAL pipeline trench in Mecklenburg-Western Pomerania], Brandenburg. Geowiss. Beitr., 19, 3-18, 2012.

Börner, A., Janke, W., Lampe, R., Lorenz, S., Obst, K., and Schütze, K.: Geowissenschaftliche Untersuchungen an der OPAL-Trasse in Mecklenburg-Vorpommern - Geländearbeiten und erste Ergebnisse, Brandenburg. geowiss. Beitr. 18, 9-28, Cottbus, 2011.

Börner, A., Janke, W., Lorenz, S., Pisarska-Jamrozy, M., and Rother, H.: Das Jungquartär im Binnenland MecklenburgVorpommerns - glaziale Morphologie, Gewässernetzentwicklung und holozäne Landnutzungsgeschichte (Exkursion G am 13 April 2012), Jahresberichte und Mitteilungen des Oberrheinischen Geologischen Vereins, N.F., 94, 287-313, Stuttgart, 2012.

Börner, A., Hrynowiecka, A., Kuznetsov, V., Stachowicz-Rybka, R., Maksimov, F., Grigoriev, V., Niska, M., and Moskal-del Hoyo, M.: Palaeoecological investigations and ${ }^{230} \mathrm{Th} / \mathrm{U}$ dating of Eemian interglacial peat sequence of Banzin (MecklenburgWestern Pomerania, NE-Germany), Quatern. Int., 386, 122-136, 2015.

Börner, A., Hrynowiecka, A., Stachowicz-Rybka, R., Niska, M., Moskal-del Hoyo, M., Kuznetsov, V., Maksimov, F., and Petrov, A.: Palaeoecological investigations and ${ }^{230} \mathrm{Th} / \mathrm{U}$ dating of the Eemian Interglacial peat sequence from NeubrandenburgHinterste Mühle (Mecklenburg-Western Pomerania, NE Germany), Quatern. Int., 467, 62-78, 2018.

Böse, M., Lüthgens, C., Lee, J. R., and Rose, J.: Quaternary glaciations of northern Europe, Quaternary Sci. Rev., 44, 1-25, 2012.

Bremer, F.: Geologische Übersichtskarte MecklenburgVorpommern 1:500000, 2. ed., Landesamt für Umwelt, Naturschutz und Geologie Mecklenburg-Vorpommern, Güstrow, 2000.

Brauer, A., Schwab, M. J., Brademann, B., Pinkerneil, S., and Theuerkauf, M.: Tiefer See - a key site for lake sediment research in NE Germany, DEUQUA Spec. Pub., this volume, 2019.

Brinker, B., Harten-Buga, H., Staude, A., Jantzen, D., and Orschiedt, J.: Perimortem Lesions on Human Bones from the
Bronze Age Battlefield in the Tollense Valley: An Interdisciplinary Approach, in: Prehistoric Warfare and Violence - Quantitative and Qualitative Approaches, edited by: Dolfini, A., Crellin, R. J., Horn, C., and Uckelmann, M., 39-60, Springer, 2018.

Brumme, J.: Three-dimensional microfabric analyses of Pleistocene tills from the cliff section Dwasieden on Rügen (Baltic Sea Coast): Micromorphological evidence for subglacial polyphase deformation, PhD thesis, University of Greifswald, Germany, 250 pp., 2015.

Brumme, J., Hüneke, H., and Phillips, E.: Micromorphology and clast microfabrics of subglacial traction tills at the sea-cliff Dwasieden: evidence of polyphase syn- and post-depositional deformation, DEUQUA Spec. Pub., this volume, 2019.

Czymzik, M., Muscheler, R., Brauer, A., Adolphi, F., Ott, F., Kienel, U., Dräger, N., Słowinski, M., Aldahan, A., and Possnert, G.: Solar cycles and depositional processes in annual 10Be from two varved lake sediment records, Earth Planet. Sc. Lett., 428, 44-51, 2015.

Deecke, W.: Geologie von Pommern, Gebrüder Bornträger, 302 pp., 1907.

Dräger, N., Wulf, S., Kienel, U., Dulski, P., Ott, F., Słowinski, M., Theuerkauf, M., and Brauer, A.: High-resolution microfacies analysis and tephrochronology of varved sediments from Lake Tiefer See (NE Germany), Geophysical Research Abstracts, EGU2014-2411, 2014.

Erd, K.: Pollenanalytische Gliederung des Pleistozäns der Deutschen Demokratischen Republik, Z. Geol. Wissenschaft., 1, 1087-1103, 1973.

Flohr, S., Brinker, U., Schramm, A., Kierdorf, U., Staude, A., Piek, J., Jantzen, D., Hauenstein, K., and Orschiedt, J.: Flint arrowhead embedded in a human humerus from the Bronze Age site in the Tollense Valley, Germany - a high-resolution micro-CT study to distinguish antemortem from perimortem projectile trauma to bone, Int. J. Paleopathol., 9, 76-81, 2015.

Gehl, O.: Neue Ergebnisse über das marine Eem und zur Gliederung des Jungpleistozäns in NW-Mecklenburg, Geologie, 10, 396408, 1961.

Gehrmann, A.: The multi-stage structural development of the Upper Weichselian Jasmund glacitectonic complex (Rügen, NE Germany), PhD thesis, University of Greifswald, Germany, 235 pp. 2018.

Gehrmann, A. and Harding, C.: Geomorphological Mapping and Spatial Analyses of an Upper Weichselian Glacitectonic Complex based on LiDAR Data, Jasmund Peninsula (NE Rügen), Germany, Geosciences, 8, 208, https://doi.org/10.3390/geosciences8060208, 2018.

Gehrmann, A., Hüneke, H., Meschede, M., and Phillips, E. R.: 3D microstructural architecture of deformed glacigenic sediments associated with large-scale glacitectonism, Jasmund Peninsula (NE Rügen), Germany, J. Quaternary Sci., 32, 213 230, https://doi.org/10.1002/jqs.2843, 2017.

Gehrmann, A., Meschede, M., Hüneke, H., and Pedersen, S. A. S.: Sea cliff at Kieler Ufer (Pleistocene stripes 11-16) - Large-scale architecture and kinematics of the Jasmund Glacitectonic Complex, DEUQUA Spec. Pub., this volume, 2019.

Geinitz, E.: Geologie Mecklenburgs - I. Teil, inklusive geologische Übersichtskarte von Mecklenburg, Hofbuchdruckerei Carl Hinstorff, 200 pp., Rostock, 1922. 
German Stratigraphic Commission, Stratigraphic Table of Germany 2016, edited by: Menning, M. and Hendrich, A., Potsdam, 2016.

Groth K.: Zur glazitektonischen Entwicklung der Stauchmoräne Jasmund/Rüge, Schriftenreihe des Landesamtes für Umwelt, Naturschutz und Geologie Mecklenburg-Vorpommern, 3, 39-49, 2003.

Grundmann, L. (Ed.): Das Müritzgebiet - Ergebnisse der landeskundlichen Bestandsaufnahme im Raum Waren, Klink, Federow und Rechlin, in: Werte der deutschen Heimat 60, 282 pp., Leipzig, 1999.

Hardt, J. and Böse, M.: The timing of the Weichselian Pomeranian ice marginal position south of the Baltic Sea: A critical review of morphological and geochronological results, Quatern. Int., 478, 51-58, 2018.

Hardt, J., Lüthgens, C., Hebestreit, R., and Böse, M.: Geochronological and geomorphological investigation at the presumed Frankfurt ice marginal position in northeast Germany, Quaternary Sci. Rev., 154, 85-99, 2016.

Hermsdorf, N. and Strahl, J.: Eemian deposits in the Brandenburg area, Brandenburg, Geowiss. Beitr., 15, 23-55, 2008.

Houmark-Nielsen, M.: Extent, age and dynamics of Marine Isotope Stage 3 glaciation in the southwestern Baltic Basin, Boreas, 39, 343-359, 2010.

Hughes, A. L. C., Gyllencreutz, R., Lohne, Ø. S., Mangerud, J., and Svendsen, J. I.: The last Eurasian ice sheet - a chronological database and time-slice reconstruction, DATED-1, Boreas, 45, $1-45,2016$.

Janke, W.: Zur Genese der Flusstäler zwischen Uecker und Warnow (Mecklenburg-Vorpommern), Greifswalder Geographische Arbeiten, 26, 39-44, 2002.

Janke, W.: Holozän im Binnenland, in: Geologie von MecklenburgVorpommern, edited by: Katzung, G., 265-284, Stuttgart, 2004.

Jantzen, D., Brinker, U., Orschiedt, J., Heinemeier, J., Piek, J., Hauenstein, K., Krüger, J., Lidke, G., Lübke, H., Lampe, R., Lorenz, S., Schult, M., and Terberger, T.: A Bronze Age battlefield? Weapons and trauma in the Tollense Valley, North-Eastern Germany, Antiquity, 85, 417-433, 2011.

Jantzen, D., Lidke, G., Dräger, J., Krüger, J., Rassmann, K., Lorenz, S., and Terberger, T.: An early Bronze Age causeway in the Tollense Valley, Mecklenburg-Western Pomerania - The starting point of a violent conflict 3300 years ago?, Bericht der RömischGermanischen Kommission, 95, 13-49, 2014.

Kaiser, K.: Die hydrologische Entwicklung der Müritz im jüngeren Quartär. Befunde und ihre Interpretation. Zeitschrift für Geomorphologie, N.F. Supplement-Band, 112, 143-176, 1998.

Kaiser, K., De Klerk, P., and Terberger, T.: Die "Riesenhirschfundstelle" von Endingen: geowissenschaftliche und archäologische Untersuchungen an einem spätglazialen Fundplatz in Vorpommern, E\&G Quaternary Sci. J., 49, 102-123, https://doi.org/10.3285/eg.49.1.07, 1999.

Kaiser, K., Rother, H., Lorenz, S., Gärtner, P., and Papenroth, R.: Geomorphic evolution of small river-lake-systems in northeast Germany during the Late Quaternary, Earth Surf. Proc. Land., 32, 1516-1532, 2007.

Kaiser, K., Hilgers, A., Schlaak, N., Jankowski, M., Kühn, P., Bussemer, S., and Przegietka, K.: Palaeopedological marker horizons in northern central Europe: characteristics of Lateglacial Usselo and Finow soils, Boreas, 38, 591-609, 2009.
Kaiser, K., Lorenz, S., Germer, S., Juschus, O., Küster, M., Libra, J., Bens, O., and Hüttl, R. F.: Late Quaternary evolution of rivers, lakes and peatlands in northeast Germany reflecting past climatic and human impact - an overview, E\&G Quaternary Sci. J., 61, 103-132, https://doi.org/10.3285/eg.61.2.01, 2012.

Kaiser, K., Kobel, J., Küster, M., and Schwabe, M. (Eds.): Neue Beiträge zum Naturraum und zur Landschaftsgeschichte im Teilgebiet Serrahn des Müritz-Nationalparks, Forschung und Monitoring, 4, 282 pp., 2015.

Katzung, G.: Geologie von Mecklenburg-Vorpommern, 580 pp., Stuttgart, 2004

Kenzler, M. and Hüneke, H.: Sea cliff at Glowe: Stratigraphy and absolute age chronology of the Jasmund Pleistocene sedimentary record, DEUQUA Spec. Pub., this volume, 2019.

Kenzler, M., Tsukamoto, S., Meng, S., Thiel, C., Frechen, M., and Hüneke, H.: Luminescence dating of Weichselian interstadial sediments from the German Baltic Sea coast, Quat. Geochronol., 30, 215-256, 2015.

Kenzler, M., Tsukamoto, S., Meng, S., Frechen, M., and Hüneke, H.: New age constraints from the SW Baltic Sea area - implications for Scandinavian Ice Sheet dynamics and palaeoenvironmental conditions during MIS 3 and early MIS 2, Boreas, 46, 34-52, 2017.

Kenzler, M., Rother, H., Hüneke, H., Frenzel, P., Strahl, J., Tsukamoto, S., Li, Y., Meng, S., Gallas, J., and Frechen, M. A multi-proxy palaeoenvironmental and geochronological reconstruction of the Saalian-Eemian-Weichselian succession at Klein Klütz Höved, NE Germany, Boreas, 47, 114-136, 2018.

Kienel, U., Dulski, P., Ott, F., Lorenz, S., and Brauer, A.: Recently induced anoxia leading to the preservation of seasonal laminae in two NE-German lakes, J. Paleolimnol., 50, 535-544, 2013.

Kopp, D.: Die periglaziäre Deckzone (Geschiebedecksand) im nordostdeutschen Tiefland und ihre bodenkundliche Bedeutung, Berichte der Geologischen Gesellschaft in der DDR, 10, 739$771,1965$.

Kopp, D.: Kryogene Perstruktion und ihre Beziehung zur Bodenbildung im Moränengebiet, in: Periglazial, Löss - Paläolithikum im Jungpleistozän der DDR, edited by: Richter, H., Haase, G., Lieberoth, I., and Ruske, R., Petermann. Geogr. Mitt., 274, 269279, 1970.

Krüger, J., Nagel, F., Nagel, S., Jantzen, D., Lampe, R., Dräger, J., Lidke, G., Mecking, O., Schüler, T., and Terberger, T.: Bronze Age tin rings from the Tollense valley in northeastern Germany, Praehist. Z., 87, 29-43, 2012.

Küster, M.: Holozäne Landschaftsentwicklung der Mecklenburgischen Seenplatte: Relief- und Bodengenese, hydrologische Entwicklung sowie Siedlungs- und Landnutzungsgeschichte in Nordostdeutschland, $\mathrm{PhD}$ thesis, University of Greifswald, Germany, 238 pp., 2014.

Küster, M.: The Müritzeum in Waren (Müritz): Natural History Museum and modern Nature Discovery Center, DEUQUA Spec. Pub., this volume, 2019.

Küster, M. and Preusser, F.: Late Glacial and Holocene aeolian sands and soil formation from the Pomeranian outwash plain (Mecklenburg, NE-Germany), E\&G Quaternary Sci. J., 58, 156163, https://doi.org/10.3285/eg.58.2.04, 2010.

Küster, M., Janke, W., Meyer, H., Lorenz, S., Lampe, R., Hübener, T., and Klamt, A.-M.: Zur jungquartären Landschaftsentwicklung der Mecklenburgischen Kleinseenplatte: Geomorphologis- 
che, bodenkundliche und limnogeologische Untersuchungen am Krummen See bei Blankenförde (Mecklenburg), in: Forschung und Monitoring, Bd. 3, Nationalparkamt Müritz, 78 pp., Geozon, Greifswald, 2012.

Lampe, R., Lorenz, S., Janke, W., Meyer, H., Küster, M., Hübener, T., and Schwarz, A.: Zur Landschafts- und Gewässergeschichte der Müritz. Forschung und Monitoring, Band 2, Nationalparkamt Müritz, 94 pp., 2009.

Lane, C. S., Klerk, D. P., and Cullen, V. L.: A tephrochronology for the Lateglacial palynological record of the Endinger Bruch (Vorpommern, north-east Germany), J. Quaternary Sci., 27, 141$149,2012$.

Lidke, G. and Lorenz, S.: The Bronze Age battlefield in the River Tollense Valley - Conflict Archaeology and Holocene landscape reconstruction, DEUQUA Spec. Pub., this volume, 2019.

Lidke, G., Jantzen, D., Lorenz, S., and Terberger, T.: The Bronze Age battlefield in the Tollense Valley, Mecklenburg-Western Pomerania, northeast Germany - conflict scenario research, in: Conflict archaeology: Materialities of collective violence in late prehistoric and early historic Europe, edited by: Fernández-Götz, M. and Roymans, N., Themes in Contemporary Archaeology 5, 61-68, 2018.

Liedtke, H.: Phasen periglaziär-geomorphologischer Prägung während der Weichseleiszeit im norddeutschen Tiefland, Z. Geomorphol., 93, 69-94, 1993.

Litt, T., Behre, K.-E., Meyer, K.-D., Stephan, H.-J., and Wansa, S.: Stratigraphische Begriffe für das Quartär des norddeutschen Vereisungsgebietes, E\&G Quaternary Sci. J., 56, 765, https://doi.org/10.3285/eg.56.1-2.02, 2007.

Lorenz, S.: Die spätpleistozäne und holozäne Gewässernetzentwicklung im Bereich der Pommerschen Haupteisrandlage Mecklenburgs, Dissertation Universität Greifswald, 349 pp., 2007.

Lorenz, S.: Durchbruchstalgenese im Bereich der Pommerschen Haupteisrandlage Mecklenburgs, Abhandlungen der Geologischen Bundesanstalt, 62, 183-188, 2008.

Lorenz, S. and Schult, M.: Das Durchbruchstal der Mildenitz bei Dobbertin (Mecklenburg) - Untersuchungen zur spätglazialen und holozänen Talentwicklung an Terrassen und Schwemmfächern, Meyniana, 56, 47-68, 2004.

Lorenz, S., Rother, H., and Kaiser, K.: Die jungquartäre Gewässernetzentwicklung der Krakower Seen und der Nebel (Mecklenburg) erste Ergebnisse, Greifswalder Geographische Arbeiten, 26, 79-82, 2002.

Lorenz, S., Schult, M., Lampe, R., Spangenberg, A., Michaelis, D., Meyer, H., Hensel, R., and Hartleib, J.: Geowissenschaftliche und paläoökologische Ergebnisse zur holozänen Entwicklung des Tollensetals, in: Tod im Tollensetal - Forschungen zu den Hinterlassenschaften eines bronzezeitlichen Gewaltkonfliktes in Mecklenburg-Vorpommern. Teil 1: Die Forschungen bis 2011 - Beiträge zur Ur- und Frühgeschichte MecklenburgVorpommerns, edited by: Jantzen, D., Orschiedt, J., Piek, J., and Terberger, T., 50, 37-60, Landesamt für Kultur und Denkmalpflege, Schwerin, 2015.

Lorenz, S., Rother, H., Kenzler, M., and Kaphengst, S.: Late glacial to Holocene dune development at Lake Krakower See, DEUQUA Spec. Pub., this volume, 2019.
Ludwig, A. O.: Untersuchung des Pleistozäns der Ostseeküste von der Lübecker Bucht bis Rügen, Geologie, Beiheft 42, 143 pp., 1964.

Ludwig, A. O.: Cyprinenton und I1-Folge im Pleistozän von Nordost-Rügen und der Insel Hiddensee (südwestliche Ostsee), Z. Geol. Wissenschaft., 34, 349-377, 2006.

Ludwig, A. O.: Zwei markante Stauchmoränen: Peski/Belorussland und Jasmund, Ostseeinsel Rügen/Nordostdeutschland - Gemeinsame Merkmale und Unterschiede, E\&G Quaternary Sci. J., 60, 31, https://doi.org/10.3285/eg.60.4.06, 2011.

Lüthgens, C. and Böse, M.: Chronology of Weichselian main ice marginal positions in north-eastern Germany, E\&G Quaternary Sci. J., 60, 17, https://doi.org/10.3285/eg.60.2-3.02, 2011.

Lüthgens, C., Böse, M., and Krbetschek, M.: On the age of the young morainic morphology in the area ascribed to the maximum extent of the Weichselian glaciation in north-eastern Germany, Quatern. Int., 222, 72-79, 2010a.

Lüthgens, C., Krbetschek, M., Böse, M., and Fuchs, M.C.: Optically stimulated luminescence dating of fluvioglacial (sandur) sediments from north-eastern Germany, Quat. Geochronol., 5, 237-243, 2010b.

Lüthgens, C., Böse, M., and Preusser, F.: Age of the Pomeranian ice-marginal position in northeastern Germany determined by Optically Stimulated Luminescence (OSL) dating of glaciofluvial sediments, Boreas, 40, 598-615, 2011.

Mehlhorn, P., Winkler, L., Grabbe, F. C., Kenzler, M., Gehrmann, A., Hüneke, H., and Rother, H.: Coastal cliff at Lenzer Bach on Jasmund Peninsula, Rügen Island (Pleistocene Stripe 4): Reconstructed history of glacitectonic deformation based on fold geometry and microstructural mapping, DEUQUA Spec. Pub., this volume, 2019.

Menzel-Harloff, H. and Meng, S.: Spätsaalezeitliche und eemzeitliche Makrofaunen aus dem Kliffaufschluss Klein Klütz Höved (NW-Mecklenburg): mit Erstnachweisen von Belgrandia germanica (Gastropoda: Hydrobiidae), Pupilla loessica (Gastropoda: Pupillidae) und Lagurus lagurus (Mammalia: Cricetidae) für Mecklenburg-Vorpommern, E\&G Quaternary Sci. J., 64, 82-94, https://doi.org/10.3285/eg.64.2.03, 2015.

Müller, U.: Alt- und Mittel-Pleistozän; Jung-Pleistozän Eem-Warmzeit bis Weichsel-Hochglazial, in: Geologie von Mecklenburg-Vorpommern, edited by: Katzung, G., 226-242, Stuttgart, 2004a.

Müller, U.: Weichsel-Frühglazial in Nordwest Mecklenburg, Meyniana, 56, 81-115, 2004b.

Müller, U.: Das Relief der Quartärbasis in MecklenburgVorpommern, Neubrandenburger Geologische Beiträge, 4, 67$76,2004 \mathrm{c}$.

Müller, U. and Obst, K.: Lithostratigraphy and bedding of the Pleistocene deposits in the area of Lohme (Jasmund/Rügen), J. Geol. Sci., 34, 39-54, 2006.

Müller, U., Rühberg, N., and Krienke, H.-D.: The Pleistocene sequence in Mecklenburg-Vorpommern, in: Glacial deposits in North-East Europe, edited by: Ehlers, J., Kozarski, S., and Gibbard, P., 501-514, Rotterdam, Balkema A.A. Publishers, 1995.

Obst, K., Nachtweide, C., and Müller, U.: Late Saalian and Weichselian glaciations in the German Baltic Sea documented by Pleistocene successions at the southeastern margin of the Arkona Basin, Boreas, 46, 18-33, 2017. 
Panzig, W.-A.: Zum Pleistozän von Rügen, Terra Nostra, 6, 177200, 1995.

Pisarska-Jamroży, M., Belzyt, S., Börner, A., Hoffmann, G., Hüneke, H., Kenzler, M., Obst, K., Rother, H., and van Loon, A. J.: Evidence from seismites for glacio-isostatically induced crustal faulting in front of an advancing land-ice mass (Rügen Island, SWBaltic Sea), Tectonophysics, 745, 338-348, 2018.

Price, T. D., Frei, R., Brinker, U., Lidke, G., Terberger, T., Frei, K. M., and Jantzen, D.: Multi-isotope proveniencing of human remains from a Bronze Age battlefield in the Tollense Valley in northeast Germany, Journal of Archaeological and Anthropological Science, https://doi.org/10.1007/s12520-017-0529-y, 2017.

Rother, H., Lorenz, S. , Börner, A., Kenzler, M., Siermann, N., Fülling, A., Hrynowiecka, A., Forler, D., Kuznetsov, V., Maksimov, F., and Starikova, A.: The terrestrial Eemian to late Weichselian sediment record at Beckentin (NE-Germany): First results from lithostratigraphic, palynological and geochronological analyses, Quatern. Int., 501, 90-108, 2019.

Rühberg, N.: Die Grundmoräne des jüngsten Weichselvorstoßes im Gebiet der DDR, Z. Geol. Wissenschaft., 15, 759-767, Berlin, 1987.

Rühberg, N.: Die eiszeitliche Schichtenfolge und Entwicklung im Gebiet um Neubrandenburg, in: Geologie der Region Neubrandenburg, edited by: Granitzki, K., 31-40, Neubrandenburg, 1998.

Rühberg, N.: Geologische Entstehung des Müritzgebietes, in: Die Müritz, Die Geschichte einer Landschaft und ihrer Bewohner rund um Deutschlands größten Binnensee, edited by: Müller, A., 24-30, Waren, 1999.

Rühberg, N. and Krienke, H.-D.: Zur Geschiebeführung der Weichselgrundmoräne im westlichen Odermündungsgebiet, Z. Geol. Wissenschaft., 5, 805-813, 1977.

Rühberg, N., Schulz, W., Bülow, W.v., Müller, U., Krienke, H.D., Bremer, F., and Dann, T.: Mecklenburg-Vorpommern, in: Das Quartär Deutschlands, edited by: Benda, L., 95-115, Berlin, 1995.

Rühberg, N., Strahl, J., and Keding, E.: Die eiszeitliche Schichtenfolge und Entwicklung im Gebiet um Neubrandenburg, in: Geologie der Region Neubrandenburg, edited by: Granitzki, K., 3140, Neubrandenburg, 1998.

Schlaak, N.: Studie zur Landschaftsgenese im Raum Nordbarnim und Eberswalder Urstromtal, Berliner Geographische Arbeiten, 76, 1-145, 1993.

Schlaak, N.: Der Finowboden - Zeugnis einer begrabenen weichselspätglazialen Oberfläche in den Dünengebieten Nordostbrandenburgs, Münchener Geographische Abhandlungen, A49, 143148, 1998.

Schulz, W.: Abriß der Quartärstratigraphie Mecklenburgs, Archiv Freunde der Naturgeschichte Mecklenburgs, XIII, 99-119, 1967.
Schulz, W.: Die quartärgeologische Kartierung in den Bezirken Rostock, Schwerin und Neubrandenburg bis zum Jahre 1967, Petermanns Geogr. Mitt., 115, 307-315, 1971.

Schwab, M. J., Błaszkiewicz, M., Raab, T., Wilmking, M., and Brauer, A. (Eds.): ICLEA Final Symposium 2017: Abstract Volume \& Excursion Guide, Scientific Technical Report STR 17/03, GFZ German Research Centre for Geosciences, https://doi.org/10.2312/GFZ.b103-17037, 2017.

Steinich G.: Endogene Tektonik in den Unter-MaastrichtVorkommen auf Jasmund (Rügen), Geologie, Suppl. 21/22, 207 pp., 1972.

Steinich, G.: Die stratigraphische Einordnung der Rügen-Warmzeit, J. Geol. Sci., 20, 125-154, 1992.

Strahl, J., Keding, E., Steinich, G., Frenzel, P., and Strahl, U.: Eine Neubearbeitung der eem- und frühweichselzeitlichen Abfolge am Klein Klütz Höved, Mecklenburger Bucht, E\&G Quaternary Sci. J., 44, 62-78, https://doi.org/10.3285/eg.44.1.07, 1994.

Terberger, T., De Klerk, P., Helbig, H., Kaiser, K., and Kühn, P.: Late Weichselian landscape development and human settlement in Mecklenburg-Vorpommern (NE Germany), E\&G Quaternary Sci. J., 54, 138-175, https://doi.org/10.3285/eg.54.1.08, 2004.

TGL 25232: Fachbereichstandard Geologie - Analyse des Geschiebebestandes quartärer Grundmoränen, Zentrales Geologisches Institut, Berlin, 1971.

Theuerkauf, M., Dräger, N., Kienel, U., Kuparinen, A., and Brauer, A.: Effects of changes in land management practices on pollen productivity of open vegetation during the last century derived from varved lake sediments, Holocene, 25, 733-744, 2015.

van der Maaten, E., van der Maaten-Theunissen, M., Buras, A., Scharnweber, T., Simard, S., Kaiser, K., Lorenz, S., and Wilmking, M.: Can We Use Tree Rings of Black Alder to Reconstruct Lake Levels? A Case Study for the Mecklenburg Lake District, Northeastern Germany, PLoS ONE, 10, 0137054, https://doi.org/10.1371/journal.pone.0137054, 2015.

von Bülow, W.: Geologische Entwicklung Südwest-Mecklenburgs seit dem Ober-Oligozän, Schriftenreihe für Geowissenschaften, 11, 413 pp., Berlin, 2000.

von Bülow, W. and Börner, A.: Loosen Formation, in: LithoLex [Online-Database], BGR, Hannover, last updated: 21 January 2019, Record No. 10000021, available at: https://litholex. bgr.de, last access: 26 June 2019.

Zawiska, I., Lorenz, S., Börner, A., Niessner, D., Słowinski, M., Theuerkauf, M., Pieper, H., and Lampe, R.: Late-glacial to Early Holocene lake basin and river valley formation within Pomeranian moraine belt near Dobbertin (MecklenburgVorpommern, NE Germany), Geophysical Research Abstracts, Vol. 16, EGU2014, 2014. 